\title{
PERKECAMBAHAN, PERAKARAN DAN PERTUMBUHAN HIPOKOTIL BENIH KOPI ARABIKA VARIETAS CATUAI PADA APLIKASI BERBAGAI KONSENTRASI GIBERELIN (GA3)
}

\author{
Muhammad Kadir ${ }^{1)}$, Image Rainy Clarita ${ }^{1)}$, Syatrawati'), Nur Amalika Sagita ${ }^{1)}$ \\ Jurusan Budidaya Tanaman Perkebunan, Politeknik Pertanian Negeri Pangkep \\ Jl. Poros Makassar Pare-Pare KM 83 Mandalle, Kab. Pangkep \\ Korespondensi: m.hamkadir@gmail.com
}

\begin{abstract}
ABSTRAK
Perbanyakan massal tanaman kopi membutuhkan benih dengan viabilitas tinggi ditandai dengan daya kecambah dan pertumbuhan kecambah yang baik. Salah satu cara untuk memacu viabilitas benih kopi adalah pemberian Zat Pengatur Tumbuh Giberelin (Gibberelic acid) atau $\mathrm{GA}_{3}$. Penelitian bertujuan untuk mengetahui pengaruh beberapa konsentrasi $\mathrm{GA}_{3}$ terhadap viabilitas benih kopi arabika varietas Catuai. Percobaan menggunakan Rancangan Acak Lengkap (RAL). Perlakuan dengan 5 taraf konsentrasi GA 3 ditambah Kontrol, yaitu masingmasing 0 (Kontrol), 100, 200, 300, 400 dan 500 ppm dimana benih kopi direndam selama 24 jam sebelum dikecambahkan. Hasil Penelitian menunjukkan bahwa konsentrasi 300 dan 200 ppm $\mathrm{GA}_{3}$ menunjukkan hasil terbaik untuk persentase daya kecambah dan laju. Perkecambahan, namun tidak terlihat adanya pengaruh nyata terhadap karakter panjang akar maupun hipokotil.
\end{abstract}

Kata Kunci: Kopi Arabika, Catuai, Konsentrasi, GA, Perkecambahan

\begin{abstract}
The mass propagation of coffee plants requires seeds with high-viability characterized by good germination and germination growth. One way to increase the viability of coffee seeds is the provision of Gibberellic Acid $\left(\mathrm{GA}_{3}\right)$. This study aims to determine the effect of several concentrations of $\mathrm{GA}_{3}$ on the viability of Catuai variety of Arabica coffee. The experiment used a completely randomized design (CRD). Treatment with Control and 5 levels of $\mathrm{GA}_{3}$ concentration, namely 0 (Control), 100, 200, 300, 400 and 500 ppm respectively where coffee seeds were soaked for 24 hours before being germinated. The results showed that the concentrations of 300 and $200 \mathrm{ppm} \mathrm{GA}_{3}$ showed the best results for germination percentage and rate Germination, however, did not appear to have a significant effect on the root and hypocotyl length.
\end{abstract}

Keywords: Arabica Coffee, Catuai, Concentration, $\mathrm{GA}_{3}$, Germination

\section{PENDAHULUAN}

Pembibitan merupakan aspek vital dalam budidaya kopi (termasuk komoditi perkebunan / tanaman tahunan lainnya) karena proses ini akan mempengaruhi kondisi atau produktivitas tanaman kopi setelah dewasa. Proses pembibitan membutuhkan waktu yang relatif lama sehingga dapat berpengaruh pada masa produksi tanaman kopi dan apabila terjadi kegagalan daam pembibitan atau penyediaan bibit yang baik maka kerugian akan sangat besar selain dari 
segi materi juga waktu yang terbuang (Mulyani et al., 2018). Praktek pembibitan untuk perbanyakan tanaman kopi dapat dilakukan dengan cara vegetatif dan generatif. Perbanyakan generatif menggunakan bagian generatif tanaman kopi untuk perbanyakan, yaitu benih (biji), sementara perbanyakan dengan cara vegetatif dapat melalui setek dan sambung menggunakan bagian vegetatif tanaman kopi seperti daun, ranting, cabang, dan akar.

Untuk perbanyakan massal, perbanyakan tanaman melalui biji merupakan pilihan utama dikarenakan kemudahan dan efektifitas perbanyakannya. Perbanyakan dengan biji tentu melalui proses pengecambahan benih, baik untuk dijadikan tanaman utama dari biji maupun untuk dilanjutkan sebagai bagian perbanyakan vegetatif (batang bawah sambung pucuk dan lain-lain). Proses pengecambahan benih kopi adalah fase yang paling penting dan sering mengalami kendala karena dormansi benih kopi. Menurut Andini dan Rizka (2018), karakteristik biji yang dimiliki oleh benih kopi mengakibatkan lamanya proses perkecambahan, sehingga diperlukan upaya untuk mempercepat perkecambahan benih kopi.

Untuk memaksimalkan perkecambahan benih kopi perlu diperlakuan sebelum penanaman. Perlakuan pada benih dapat dilakukan dengan berbagai cara antara lain dengan cara kimiawi. Tujuannya adalah menjadikan agar kulit biji lebih mudah dimasuki air pada waktu proses imbibisi. Biji kopi sebenarnya tidak mengalami dormansi, artinya buah yang tingkat kematangan fisiologi memenuhi syarat untuk dipanen, biji tersebut bisa tumbuh bila dibibitkan. Walaupun demikian untuk mendapatkan viabilitas yang homogen disarankan menggunakan Giberelin (Gibberellic acid), dengan konsentrasi tertentu untuk memacu perkecambahan (Pertiwi et al., 2016). Menurut Lestari et al. (2016), pertumbuhan kecambah kopi arabika dipengaruhi oleh keseimbangan ZPT eksogen yaitu Giberelin $\left(\mathrm{GA}_{3}\right)$ dengan ZPT Endogen yaitu asam absisat (ABA) yang terdapat didalam biji. Pemberian $\mathrm{GA}_{3}$ eksogen pada biji yang berkecambah dapat menekan aktivitas $\mathrm{ABA}$, sehingga meningkatkan aktivitas $\mathrm{GA}_{3}$ untuk mendorong perkecambahan. Hasil Penelitian Yang et al., (2020), menunjukkan bahwa pada suhu dengan berfluktuasi rendah perlakuan $\mathrm{GA}_{3}$ mampu meningkatkan persentase perkecambahan benih. Beberapa hasil penelitian dan uraian tersebut menunjukkan bahwa pemberian $\mathrm{GA}_{3}$ mampu meningkatkan perkecambahan benih kopi. Gibberellin berperan dalam pembentangan dan pembelahan sel, pemecahan dormansi biji sehingga biji dapat berkecambah, mobilisasi endosperm cadangan selama pertumbuhan awal embrio, pemecahan dormansi tunas, pertumbuhan dan perpanjangan batang, perkembangan bunga dan buah. Senyawa $\mathrm{GA}_{3}$ aktivitas enzim hidrolitik sehingga tersedia nutrisi yang cukup untuk tunas tumbuh lebih cepat (Lestari et al., 2016 ; Siregar, 2017) 
Kabupaten Toraja merupakan sentra utama penghasil kopi di Sulawesi Selatan terutama jenis Arabika yang sudah terkenal bahkan ke seluruh dunia. Salah satu jenis Kopi Arabica yang sudah mendunia adalah varietas Catuai. Varietas kopi catuai memiliki buah yang umumnya berwarna merah dan kuning. Catuai memiliki tingkat keasaman yang tinggi. Varietas ini merupakan turunan dari Varietas Caturra yang disilangkan dengan salah satu varietas dari Brazil, mundo novo yang dikenal sangat nikmat. Catuai dapat menghasilkan kenikmatan yang tiada tara saat diseduh, bahkan ketika bijinya di-roasting hingga gelap. Tanaman varietas catuai ini banyak dibudidayakan di Indonesia dan Amerika Selatan.

Guna meningkatkan kembali produktivitas dan upaya pengembangan kopi arabika terutama varietads Catuai yang saat ini mulai berkurang dikarenakan banyaknya varietas baru, maka upaya pengembangan dilakukan melalui penelitian yang bertujuan memperoleh metode untuk meningkatkan viabilitas pembibitan kopi khususnya carieats Catuai. Mengetahui konsentrasi $\mathrm{GA}_{3}$ terbaik yang dapat meningkatkan viabilitas benih kopi arabika varietas Catuai adalah penting dalam pembudidayaan pada vase perkecambahan untuk pembibitan kopi.

\section{BAHAN DAN METODE}

Penelitian ini dilaksanakan pada Desember 2019 hingga Februari 2020, di laboratorium benih dan screen house Jurusan Budidaya Tanaman Perkebunan Politeknik Pertanian Negeri Pangkajene Kepulauan, Pangkep Sulawesi Selatan. Menggunakan benih kopi arabika varietas Catuai terpilih dan terseleksi dari kebun Induk Rantepao Tana Toraja - Sulsel. Media Pengecambahan menggunakan Pasir Steril + pupuk kendang steril. Perlakuan Zat Pengatur Tumbuh $\mathrm{GA}_{3}$ yang digunakan adalah formulasi $40 \mathrm{ml} . \mathrm{L}^{-1}$. Penelitian menggunakan Rancangan Acak Lengkap (RAL) terdiri dari 6 taraf perlakuan konsentrasi GA $_{3}$ yaitu Kontrol (Tanpa $\mathrm{GA}_{3}$ ), 100 ppm, 200 ppm, 300 ppm, 400 ppm, dan 500 ppm. Masing-masing diulang sebanyak 3 kali, Sehingga diperoleh 18 satuan percobaan, masing-masing satuan perlakuan terdiri dari 50 benih, sehingga total benih kopi yang dikecambahkan adalah 900 biji.

Benih dipilih kerseluruhan dari buah yang telah berwarna merah. Biji dipisahkan dengan kulit buah menggunakan sarung tangan. Untuk menentukan benih yang baik yaitu dengan cara biji kopi dimasukkan kedalam air, biji yang tenggelam merupakan biji yang akan digunakan sebagai benih, sedangkan biji yang mengapung merupakan biji yang tidak layak digunakan. Biji yang seragam dijadikan sebagai bahan penelitian. Benih direndam dalam larutan Fungisida kontak (Bahan aktif Mankozeb: selama 15 menit agar benih terhindar dari mikroorganisme yang merugikan. Zat Pengatur Tumbuh Giberelin $\left(\mathrm{GA}_{3}\right)$ disiapkan dan 
dilakukan pengenceran sesuai masing-masing konsentrasi perlakuan, kira-kira sebanyak 400 ml yang dimasukkan kedalam wadah untuk perlakuan perendaman. Benih yang telah disiapkan direndam dalam larutan $\mathrm{GA}_{3}$ sesuai konsentrasi selama 24 jam sebelum ditanam dalam bak pengecambahan.

Pengamatan dilakukan setiap hari dengan parameter: Persentase Daya Kecambah (\%), menunjukkan jumlah kecambah normal yang dihasilkan oleh benih murni pada kondisi lingkungan tertentu dalam jangka waktu yang telah ditetapkan. Presentase daya kecambah kopi dihitung pada saat benih yang dikecambahkan berumur 60 HSS. Persentase Daya kecambah dihitung menggunakan persamaan (1).

$D K=\frac{\text { Jumlah Biji Berkecambah }}{\text { Jumlah Benih yang Diuji }} \times 100 \%$

Laju Perkecambahan, adalah waktu munculnya plumula benih dari awal pengamatan berkecambah sampai akhir perngamatan. Menurut Sutopo (2012), laju perkecambahan dihitung dengan persamaan (2)

$L P=\frac{(N 1 T 1)+(N 2 T 2)+(N 3 T 3)+\cdots(N x T X)}{\sum \text { seluruh benih yang berkecambah }}$

LP = Laju perkecambahan

$\mathrm{N}$ = Jumlah benih yang berkecambah setiap hari

$\mathrm{T}$ = Jumlah waktu antara awal pengujian sampai dengan akhir dari interval pengamatan

$\mathrm{x}=$ waktu terakhir pengamatan

Panjang akar (radikula) diukur dari leher akar sampai ujung akar, pengukuran dilakukan pada saat kecambah tanaman berumur 60 hari setelah semai (HSS). Panjang hipokotil (cm) atau Tinggi kecambah diukur dari permukaan tanah sampai titik tumbuh. Pengukuran tinggi kecambah dengan menggunakan mistar. Tinggi kecambah diukur pada saat tanaman berumur 60 HSS dan rasio panjang hipokotil/akar yang merupakan rasio antara tinggi/panjang bagian tanaman diatas permukaan tanah (Hipokotil) dan dibawah permukaan Tanah (akar). Data pengamatan ditabulasi, lalu dianalis dengan menggunakan tabel Sidik Ragam (ANOVA), Bila hasil sidik ragam menunjukkan hasil yang berpengaruh nyata ( $\mathrm{F}$ hitung $>\mathrm{F}$ table $5 \%$ ) atau berbeda sangat nyata ( $\mathrm{F}$ hitung $>\mathrm{F}$ tabel 1\%), maka untuk membandingkan rata-rata perlakuan tersebut dengan menggunakan uji lanjut Beda Nyata Terkecil (BNT). 


\section{HASIL DAN PEMBAHASAN}

\section{Pesentase Daya Kecambah (\%) dan Laju Perkecambahan}

Daya kecambah diukur melalui persentase perkecambahan (\%) menunjukkan respon adanya pengaruh perbedaan yang nyata dari perbedaan konsentrasi $\mathrm{GA}_{3}$ pada taraf kepercayaan 95\%. Hasil uji BNT 0,05 pada Tabel 1, menunjukkan bahwa perendaman dengan konsentrasi 300 ppm memberikan daya kecambah tertinggi dengan rata-rata $62 \%$, berbeda nyata dengan control (0 ppm) dan 500 ppm.

Perbedaan konsentrasi $\mathrm{GA}_{3}$ berpengaruh tidak nyata terhadap Laju perkecambahan benih setelah akumulasi perhitungan pada $60 \mathrm{HSS}$, namun gambar 1 mengkonfirmasi bahwa perlakuan perendaman dengan konsentrasi 300 ppm dengan rata-rata laju 23,1 hari adalah yang terbaik (tercepat), ada perbedaan sekitar 2 hari dengan perlakuan kontrol.

Tabel 1. Persentase daya kecambah Benih (\%) kopi Arabika Varietas Catuai pada Perendaman benih dengan berbagai konsentrasi $\mathrm{GA}_{3}$

\begin{tabular}{ccc}
\hline Konsentrasi GA 3 & Rata-rata & NPBNT \\
\hline $300 \mathrm{ppm}$ & $62,00 \mathrm{a}$ & \\
$200 \mathrm{ppm}$ & $59,00 \mathrm{a}$ & 8,96 \\
$400 \mathrm{ppm}$ & $58,00 \mathrm{a}$ & \\
$100 \mathrm{ppm}$ & $53,33 \mathrm{abc}$ & \\
$0 \mathrm{ppm}$ & $49,00 \mathrm{bc}$ & \\
$500 \mathrm{ppm}$ & $46,00 \mathrm{c}$ & \\
\hline
\end{tabular}

Keterangan: Dua angka rata-rata berturut-turut yang diikuti oleh huruf yang sama berarti berbeda tidak nyata menurut uji BNT dengan taraf $5 \%$

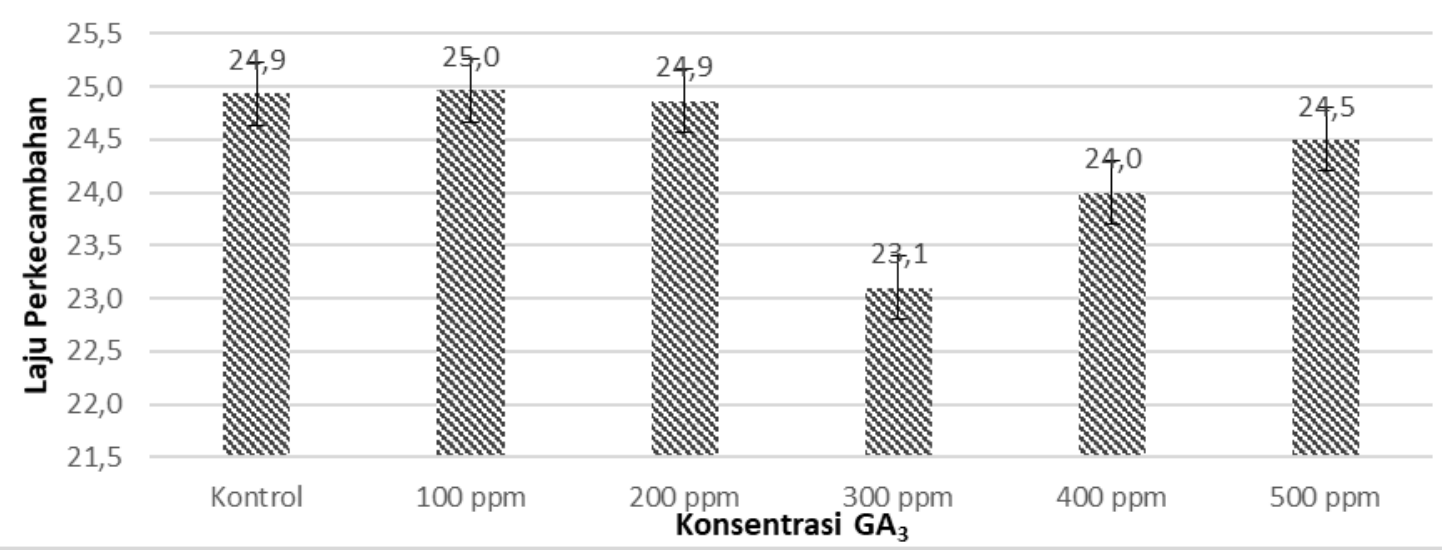

Gambar 1. Laju Perkecambahan Benih Kopi Arabika Varietas Catuai dengan pemberian berbagai konsentrasi $\mathrm{GA}_{3}$

Tabel 1 dan Gambar 1 untuk parameter perkecambahan menunjukkan bahwa peningkatan konsentrasi $\mathrm{GA}_{3}$ tidak berbanding lurus dengan kenaikan persentase Daya kecambah maupun laju perkecambahan justru pada konsentrasi 500 ppm menunjukkan nilai 
terendah artinya justru terjadi penghambatan pada konsentrasi tinggi, ini menunjukkan bahwa ada batas akumulasi $\mathrm{GA}_{3}$ yang mempu mendorong daya kecambah, namun pada konsentrasi berlebih justru memberikan hambatan pada daya kecambah benih. Menurut Lestari et al 2016) pertumbuhan kecambah kopi arabika (Coffee arabika L.) dipengaruhi oleh perimbangan zpt eksogen yaitu $\mathrm{GA}_{3}$ dengan zpt endogen yaitu asam absisat (ABA) yang terdapat didalam biji. Pemberian $\mathrm{GA}_{3}$ eksogen pada biji yang berkecambah dapat menekan aktivitas ABA. Menurut Esmaeili (2009) proses perkecambahan biji ditentukan oleh keseimbangan antara promotor dan inhibitor perkecambahan terutama $\mathrm{GA}_{3}$ dan $\mathrm{ABA}$. Selama penelitian terdapat biji kopi arabika tidak berkecambah yang disebabkan biji mengalami kekeringan, hal ini diduga embrio pada biji belum matang. Hasil penelitian mengkonfirmasi dan menunjukkan bahwa konsentrasi 300 ppm cukup memberi keseimbangan sehingga memicu daya kecambah yang lebih baik disbanding konsentrasi yang lebih tinggi.

Hasil penelitian Farida (2018), menyatakan bahwa Aplikasi ZPT menunjukkan pengaruh yang nyata pada viabiltas dan vigor (persentase perkecambahan, laju perkecambahan, dan indeks vigor) benih kopi. Hal ini menunjukkan bahwa pemberian ZPT dalam hal ini $\mathrm{GA}_{3}$ dapat memacu perkecambahan biji. Davies (2004), menyatakan bahwa cara kerja hormon dalam ZPT mampu mempercepat perkecmbahan. Cara kerja ZPT dalam perkecambahan biji diawali dengan terjadinya imbibisi air merangsang sintesis hormon, lalu hormon tersebut berdifusi ke lapisan aleuron dan merangsang sintesis enzim. Ditambahkan oleh pendapat Hopkins (1999) yang mengemukakan bahwa ZPT mengandung unsur Giberelin yang sangat berperan dalam perkecambahan biji dan memobilisasi cadangan makanan yang terdapat dalam endosperm selama pertumbuhan awal embrio. Mobilisasi tersebut diatur oleh beberapa enzim hidrolisis, terutama enzim a-amilase yang jumlahnya cukup melimpah. Fungsi dari enzim ini memecah karbohidrat menjadi mono dan oligosakarida.

\section{Pertumbuhan Akar dan Hipokotil}

Pengamatan pada karakter perakaran dan pertumbuhan batang (hipokotil) saat kopi mencapai fase serdadu, menunjukkan panjang Hipokotil dan panjang akar dipengaruhi secara tidak nyata dari efek perendaman benih pada berbagai konsentrasi $\mathrm{GA}_{3}$ saat pengecambahan. Gambar 2 menunjukkan panjang Hipokotil dan Panjang Akar Kecambah Kopi pada umur 60 Hari setelah semai. Panjang Hipokotil terpanjang adalah pada 400 ppm dan Kontrol, dan ratarata lainnya adalah 3,9 hingga $4 \mathrm{~cm}$, dan secara statistik pengaruhnya tidak nyata, sedangkan demikian pula untuk panjang akar tidak menunjukkan perbedaan yang significant, dan berada pada kisaran 2,97 (terendah pada 400 ppm) hingga 3,77 (tertinggi pada 200 ppm). 


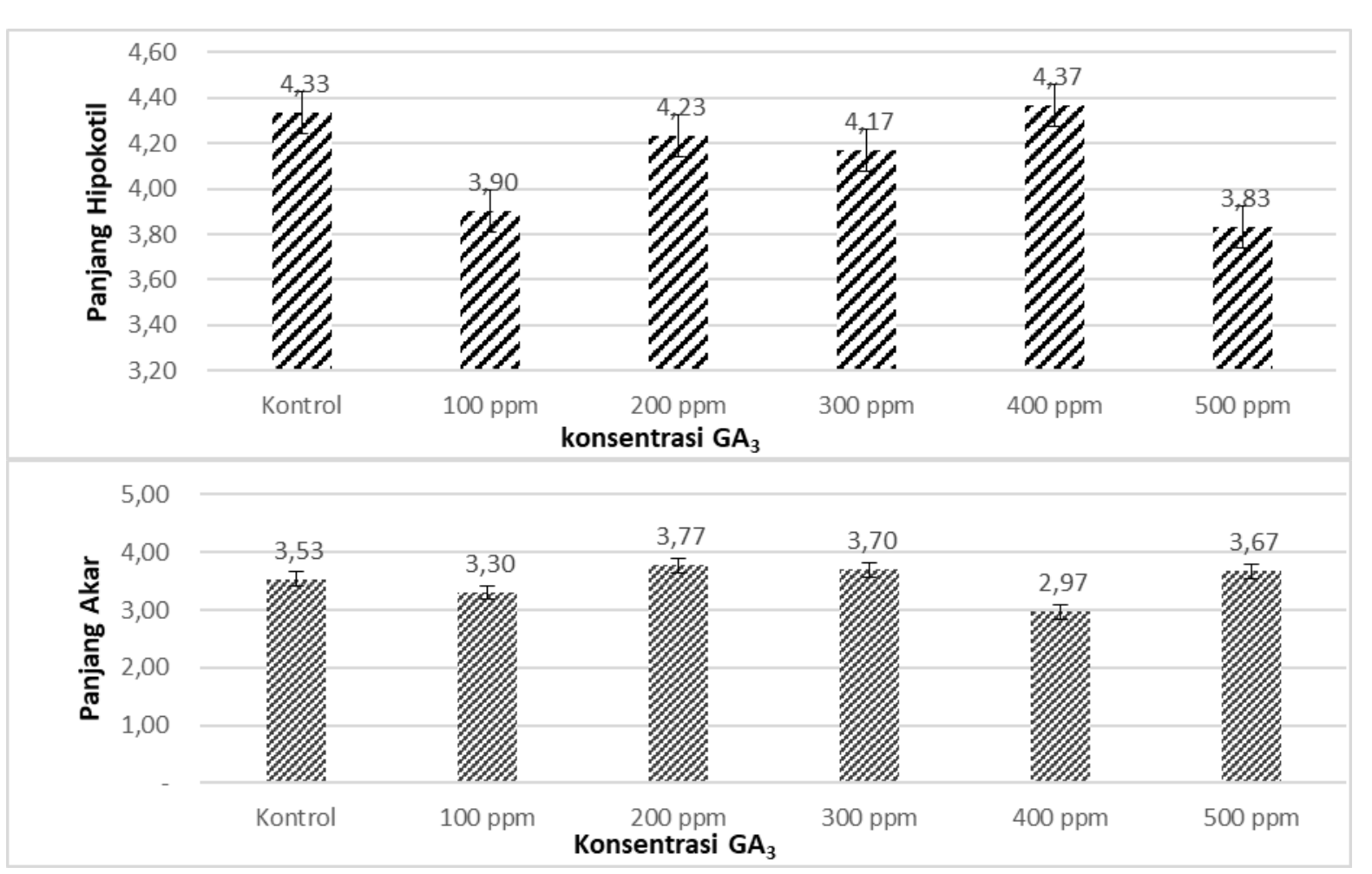

Gambar 2. Panjang Hipokotil dan Panjang Akar (cm) Bibit Kopi Arabika Varietas Catuai dengan pemberian $\mathrm{GA}_{3}$, Diamati pada 60 Hari Setelah Semai

Hasil penelitian yang dilakukan Elfianis et al. (2019) menunjukkan bahwa perlakuan perendaman dengan berbagai konsentrasi $\mathrm{GA}_{3}$ juga berpengaruh tidak nyata terhadap tinggi tanaman. Hasil tersebut sesuai dengan hasil penelitian ini dimana panjang hipokotil bibit kopi pada fase serdadu yang juga menunjukkan pengaruh yang tidak nyata. Hasil yang diperoleh tersebut diduga diakibatkan oleh keadaan zat pengatur tumbuh eksogen yang diberikan tidak akan mampu bertahan lama hingga fase pertumbuhan bibit, tetapi hanya mampu memberikan pengaruh pada pematahan dormansi benih, dengan kata lain perlakuan yang dilakukan pada benih tidak berpengaruh pada fase pertumbuhan vegetatif. Pada penelitian lain, hal berbeda dikemukakan oleh Agustin dan Aprilia (2011), dimana hasil penelitian menunjukkan perbedaan yang signifikan pada tinggi tanaman dengan perlakuan $\mathrm{GA}_{3}$ tetapi hal ini fdiamati pada konsentrasi yang jauh lebih tinggi yaitu 1500 ppm. Pengamatan panjang akar dengan pemberian $\mathrm{GA}_{3}$ dilakukan oleh Pertiwi et al. (2014) dimana diperoleh hasil bahwa pemberian $\mathrm{GA}_{3}$ dengan beberapa konsentrasi berpengaruh tidak nyata terhadap panjang akar, sejalan dengan hasil penelitian ini yang juga berbeda tidak nyata. Diagram pada Gambar 2 menunjukkan pemberian $\mathrm{GA}_{3}$ dengan konsentrasi 200 ppm dan 300 ppm memberikan akar lebih panjang daripada konsentrasi lain namun secara statistik dengan uji BNT 0.05 dinyatakan konsentrasi $\mathrm{GA}_{3}$ berpengaruh tidak nyata. Penelitian ini dan juga hasil penelitian Pertiwi, et al. (2016) tadi menunjukkan bahwa konsentrasi $\mathrm{GA}_{3}$ dan waktu perendaman menunjukkan 
pengaruh yang tidak nyata, hal ini dikarenakan perlakuan perendaman $\mathrm{GA}_{3}$ berfungsi sebagai pemecahan dormansi biji kopi (jika dianggap sebagai dormansi fisik), sedangkan kecepatan pemanjangan akar lebih dipengaruhi air yang tersedia pada saat pertumbuhan akar sudah berlangsung.

Pertumbuhan dan perkembangan tidak hanya berkaitan dengan penambahan volume sel, namun juga berkaitan dengan jumlah sel. Pertambahan jumlah sel tergantung pada kecepatan sel untuk membelah, yang dipengaruhi oleh adanya sitokinin dalam ZPT. Sehingga dengan adanya penambahan ZPT dapat mempengaruhi metabolism RNA yang berperan dalam sintesis protein melalui proses transkripsi molekul RNA. Kenaikan sintesis protein sebagai sumber tenaga dapat digunakan untuk pertumbuhan (Zulkarnaen, 2009).

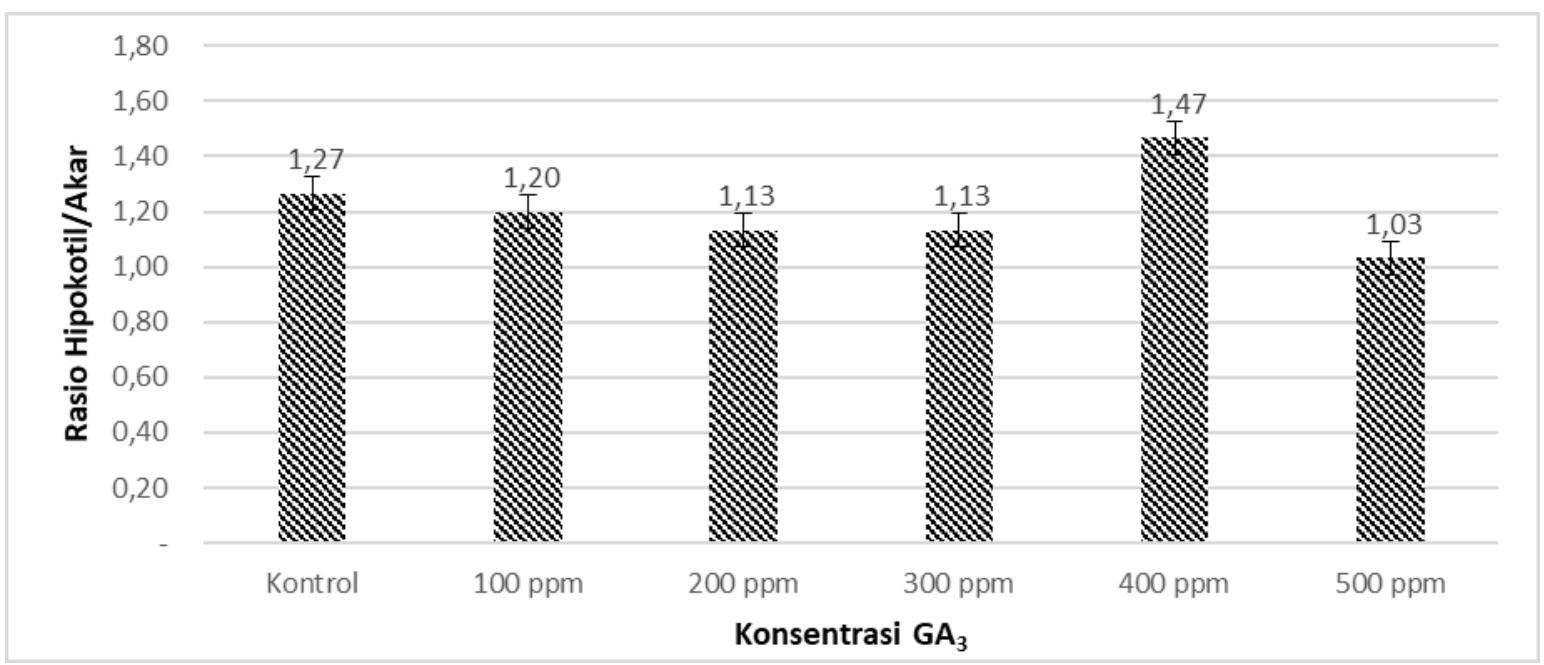

Gambar 3. Rasio Hipokotil/Akar Kopi Arabika Varietas Catuai dengan pemberian $\mathrm{GA}_{3}$, Diamati pada 60 Hari Setelah Semai

Pengaruh lebih jauh dapat diduga dari keseimbangan pertumbuhan akar dan hipokotil pasca perkecambahan, dapat diamati secara simultan rasio antara panjang batang (hipokotil dan akar). Gambar 3 menunjukkan adanya rasio hipokotil/akar yang berbeda dari berbagai perlakuan, rasio ini sesungguhnya lebih menggambarkan keseimbangan antara penyerapan hara dan pertumbuhan tanaman diatas permukaan tanah. Hubungan akar dan batang lebih ditekankan pada segi morfologi sehingga semakin banyak dan panjang akar semakin baik hasil tanaman . rasio akar dan batang menunjukkan ciri-ciri dari bentuk pertumbuhan tanaman dalam kemampuannya untuk menyerap unsur hara yang tergantung pada kondisi media tanam (Siregar et al., 2015). Hasil penelitian Sitanggang et al. (2015) juga menunjukkan bahwa pemberian ZPT Giberelin tidak nyata terhadap rasio akar tajuk, hal ini dikarenakan giberelin berpengaruh kecil terhadap pertumbuhan akar dan akan menghambat pertumbuhan akar liar. 


\section{KESIMPULAN}

1. Perendaman benih kopi arabika dengan Giberelin $\left(\mathrm{GA}_{3}\right)$ berpengaruh nyata terhadap daya kecambah, namun berpengaruh tidak nyata terhadap laju perkecambahan, panjang hipokotil, panjang akar dan ratio panjang hipokotil/ akar.

2. Perendaman benih kopi arabika dengan giberelin $\left(\mathrm{GA}_{3}\right)$ dengan konsentrasi $300 \mathrm{ppm}$ dan 200 ppm meningkatkan daya kecambah dan laju perkecambahan tapi tidak berpengaruh pada karakter pertumbuhan akar dan hipokotil.

\section{UCAPAN TERIMA KASIH}

Disampaikan terima kasih dan penghargaan kepada Direktorat Jenderal Pendidikan Vokasi, Kementerian Pendidikan dan Kebudayaan (Kemendikbud) yang telah mendanai penelitian ini.

\section{DAFTAR PUSTAKA}

Agustina, Aprillia, P. 2011. Pengaruh Pemakaian Hormon Tumbuh GA3 (Giberelin Acid) terhadap Perkecambahan dan Pertumbuhan Biji Veschaffeltia splendida H.A. Wendl. Berk. Penel. Hayati Edisi Khusus. 7A:157-160.

Andini S.N , Rizka N. 2018. Upaya Mempercepat Perkecambahan Benih Kopi Arabika (Coffea arabica L.) dan kopi Robusta (Coffea canephora var.robusta) Dengan Penggunaan Air Kelapa. Jurnal Wacana Pertanian. 14 (1): 10-16.

Davies, P.J. 2004. Plant Hormones: Biosynthesis, Signal Transduction, Action. Kluwer Academic Publisher. London.

Elfianis R, Siti H, Indah P, Jully H. 2019. Pengaruh Skarifikasi Dan Hormon Giberelin (GA 3 ) Terhadap Daya Kecambah Dan Pertumbuhan Bibit Palem Putri (Veitchia merillii). Jurnal Agroteknologi. 10 (1): 41-4.

Esmaeili, M, 2009, Ecology of Seed Dormancy and Germination of Carex divisa Huds Effects ofStratification Temperature and Salinity, International Journal of Plant Production, New York

Farida. 2018. Respon Perkecambahan Benih Kopi Pada Berbagai Tingkat Kemasakan Buah Dengan Aplikasi Zat Pengatur Tumbuh. Ziraa'ah. 43(2):166-172

Hopkins.W.G.1999.Introduction to Plant Physiology. Jhon Willey and Sons, inc. New York.

Lestari D, Risa L, Mukarlina. 2016. Pematahan Dormansi dan Perkecambahan Biji Kopi Arabika (Coffea arabika L.) dengan Asam Sulfat $\left(\mathrm{H}_{2} \mathrm{SO}_{4}\right)$ dan Giberelin $\left(\mathrm{GA}_{3}\right)$. Jurnal Protobiont. 5(1):8-13. 
Mulyani, C., Syukri, Kurniawan, R. 2018. Respon Perkecambahan Benih Kopi (Coffea, Sp) Terhadap Skarifikasi dan Perendaman Dalam Air Kelapa. Jurnal Penelitian Pertanian. 5(1): $8-15$

Pertiwi , M., M. Tahir, Made Same. 2016. Respons Pertumbuhan Benih Kopi Robusta terhadap Waktu Perendaman dan Konsentrasi Giberelin (GA3). J. AIP. 4 (1): 1-11.

Sutopo, L. 2012. Teknologi Benih. Fakultas Pertanian UNIBRAW. Malang.

Siregar, H. A. 2017. Pengaruh Giberelin (Ga3) terhadap Mutu Fisik Tandan Buah Segar Kelapa Sawit (Elaeis guineensis Jacq.). Fakultas Pertanian Institut Pertanian Bogor. [SKR]. Bogor. Hal: 29.

Sitanggang, A., Islan, Sukemi I.S. 2015. Pengaruh Pemberian Pupuk Kandang Ayam dan Zat Pengatur Tumbuh Giberelin Terhadap Pertumbuhan Bibit Kopi Arabika. JOM Faperta. 2(1)

Yang, Li-E., De-Li Peng, Zhi-Min Lib, Li Huangd, Juan Yangd, Hang Sun. 2020. Cold stratification, temperature, light, GA3, and KNO3effects on seed germination of Primula beesiana from Yunnan, China. Plant Diversity Journal, https://doi.org/10.1016/j.pld.2020.01.003

Zulkarnaen. 2009. Kultur Jaringan Tanaman. Solusi Perbanyaan Tanaman Budidaya. CV. Bumi Aksara. Jambi 